\title{
TREATY SUCCESSION IN ANNEXED TERRITORY
}

\author{
Daniel Costelloe*
}

\begin{abstract}
This article explores the question whether the territorial application of a treaty extends to unlawfully annexed territory. In this context, it examines State succession and the territorial application of treaties under general international law, as well as the moving treatyfrontiers rule and the extraterritorial application of certain treaties, specifically with respect to annexed territory. The article concludes that, while in some cases there is scope to find that a treaty applies extraterritorially in annexed territory, notably as a result of its object and purpose or its provisions, there may also be room, subject to the provisions of the treaty, for a limited form of treaty succession in such territory. Limitations to the obligation of collective non-recognition offer theoretical and practical support for this position.
\end{abstract}

Keywords: annexation of territory, extraterritorial application, moving treaty-frontiers, State succession, territorial application of treaties, Vienna Convention on the Law of Treaties, Vienna Convention on State Succession in Respect of Treaties.

\section{INTRODUCTION}

In the event of one State's annexation of part of another State's territory, the question arises whether any treaty succession occurs in this territory, even if only to some very limited extent, and if so on what basis. While the question falls within the area of State succession in respect of treaties, the topic raises as many questions concerning territorial application under the general law of treaties as it raises questions of State succession.

The general rules reflected in Article 15 of the 1978 Vienna Convention on State Succession in Respect of Treaties (VCST) ${ }^{1}$ and Article 29 of the 1969

* Senior Associate, Wilmer Cutler Pickering Hale and Dorr LLP. The author would like to thank Professor Malgosia Fitzmaurice, Professor Duncan Hollis, Dr Federica Paddeu, Dr Bart Smit Duijzentkunst, Dr Kimberley Trapp and the participants at the 2015 American Society of International Law Research Forum for their generous comments on this article. All opinions and errors remain the author's own, and should not be attributed to his law firm or to any other person.

1 Vienna Convention on the Succession of States in Respect of Treaties (concluded 23 August 1978, entered into force 6 November 1996) 1946 UNTS 3. Measured by the number of parties to the instrument it has not been successful. As of the date of writing, the VCST had a mere 22 parties. See generally Y Gamarra, 'Current Questions of State Succession Relating to Multilateral Treaties' in PM Eisemann and M Koskenniemi (eds), La succession d'Etats: la codification à l'épreuve des faits 388-9, 434 (Brill 2000). 
Vienna Convention on the Law of Treaties (VCLT) ${ }^{2}$ are part of customary international law, yet untested questions concerning the territorial application of treaties can arise where one State annexes part of another State's territory. These questions are particularly urgent where the rights of natural and legal persons in those territories and arising under a treaty may be prejudiced.

The situation in and concerning the Autonomous Republic of Crimea and the city of Sevastopol provides a practical example and gives rise to pressing questions pertaining to State succession with respect to treaties and the moving treaty-frontiers rule, as reflected in Article 15 VCST and Article 29 VCLT. The incorporation into the Russian Federation of this territory following the independence referendum in March 2014 is widely considered an annexation, ${ }^{3}$ though Russia takes the position that Crimea and Sevastopol became part of the Russian Federation pursuant to an exercise of a right to self-determination and internationally lawful means. ${ }^{4}$ General Assembly resolution 68/262 of 27 March 2014 in paragraph 6 '[c]alls upon all States, international organizations and specialized agencies not to recognize any alteration of the status of the Autonomous Republic of Crimea and the city of Sevastopol on the basis of the above-mentioned referendum [of 16 March 2014] and to refrain from any action or dealing that might be interpreted as recognizing any such altered status'. ${ }^{5}$ A European Union statement of 18 March 2014 similarly notes: 'The sovereignty, territorial integrity and independence of Ukraine must be respected. The European Union does neither recognise the illegal and illegitimate referendum in Crimea nor its outcome. The European Union does not and will not recognise the annexation of Crimea and Sevastopol to the Russian Federation. ${ }^{6}$ The United States also maintains a

2 Vienna Convention on the Law of Treaties (concluded 23 May 1969, entered into force 27 January 1980) 1155 UNTS 331.

3 See White House press release 'Background Briefing on Ukraine by Senior Administration Officials' (20 March 2014) <https://www.whitehouse.gov/the-press-office/2014/03/20/backgroundbriefing-ukraine-senior-administration-officials $>$. See further K Daugridas and JD Mortenson (eds), 'Contemporary Practice of the United States: United States Condemns Russia's Use of Force in Ukraine and Attempted Annexation of Crimea' (2014) 108 AJIL 784; T Grant, 'Annexation of Crimea' (2015) 109 AJIL 68. On the international lawfulness of the amendments to domestic legislation enabling the incorporation of Crimea into the Russian Federation, see European Commission for Democracy through Law (Venice Commission), Opinion No 763/2014, 'Opinion on "Whether Draft Federal Constitutional Law No. 462741-6 on Amending the Federal Constitutional Law of the Russian Federation on the Procedure of Admission to the Russian Federation and Creation of a New Subject within the Russian Federation Is Compatible with International Law"' (21 March 2014).

${ }^{4}$ See Address by President of the Russian Federation (18 March 2014) <http://en.kremlin.ru/ events/president/news/copy/20603> Press release on the Agreement on the Accession of the Republic of Crimea to the Russian Federation (18 March 2014) <http://en.kremlin.ru/events/ president/news/copy/20604>.

${ }^{5}$ UNGA Res 68/262 (27 March 2014) UN Doc A/RES/68/262 (adopted by 100 votes to 11; 58 abstentions).

6 'Joint statement on Crimea by the President of the European Council, Herman Van Rompuy, and the President of the European Commission, José Manuel Barroso' (18 March 2014) <http:// europa.eu/rapid/press-release_STATEMENT-14-74_en.htm>. 
position of non-recognition towards any purported change to the status of Crimea and Sevastopol. ${ }^{7}$ These events raise questions under general international law concerning the territorial application of treaties in the Crimean Peninsula that call for clarification.

The territory referred to as 'East Jerusalem' provides a further example of a territory widely considered annexed. Israel's taking of control over East Jerusalem following the Six-Days War in 1967 and measures extending Israel's jurisdiction to East Jerusalem ${ }^{8}$ were, in various terms, condemned by the Security Council in resolutions 252 (1968), 267 (1969), 298 (1971), 465 (1980), 476 (1980). ${ }^{9}$ In resolution 478 (1980), the Security Council censured the Knesset's 'Basic Law' declaring the united Jerusalem as the capital of Israel, ${ }^{10}$ determined that all legislative and administrative measures purporting to alter the status of the Holy City were null and void and must be rescinded, and decided not to recognize the Basic Law and other actions purporting to alter the character and status of Jerusalem. The Security Council further called upon all member States to accept its decision not to recognize the Basic Law and other actions, and for States that had established diplomatic missions in Jerusalem to withdraw them. ${ }^{11}$ The General Assembly in resolution 2253 (1967) likewise considered Israel's measures to change the status of Jerusalem as invalid and called upon Israel to rescind such measures and refrain from taking any further action to alter the status of Jerusalem. ${ }^{12}$ The General Assembly reiterated this call upon Israel in resolution 2254 (1967). ${ }^{13}$ Further, the Human Rights Council has considered Israel's actions in East Jerusalem to be internationally unlawful. ${ }^{14}$ Israel's

7 See White House press release, 'Background Briefing on Ukraine by Senior Administration Officials' (20 March 2014) <https://www.whitehouse.gov/the-press-office/2014/03/20/backgroundbriefing-ukraine-senior-administration-officials $>$. See Daugridas and Mortenson (n 3) 784.

8 See especially 1967 Protection of Holy Places Law (Israel).

9 UNSC Res 252 (21 May 1968) UN Doc S/RES/252, paras 2-3; UNSC Res 267 (3 July 1969) UN Doc S/RES/267, paras 3-5; UNSC Res 298 (25 September 1971) UN Doc S/RES/298, paras 24; UNSC Res 465 (1 March 1980) UN Doc S/RES/465, paras 5-6; UNSC Res 476 (30 June 1980) UN Doc S/RES/476, paras 2-5. See also UNSC Res 271 (15 September 1969) UN Doc S/RES/271, paras 3 and 5 .

${ }^{10}$ Basic Law: Jerusalem, Capital of Israel (1980) and Amendment no 1 (2000) (Israel).

11 UNSC Res 478 (20 August 1980) UN Doc S/RES/478, paras 2-5. See further Council of the European Union, 'Council conclusions on the Middle East Peace Process', paras 2 and 8 ( 8 December 2009) < http://www.consilium.europa.eu/uedocs/cms_data/docs/pressdata/en/foraff/ 111829.pdf $>$ EU Heads of Mission, 'Report on East Jerusalem' (2010). The Golan Heights offer a further example of a territory with an uncertain status. In resolution 497 (1981) example, the Security Council decided, with respect to the Golan Heights, that Israel's 'decision to impose its laws, jurisdiction and administration in the occupied Syrian Golan Heights is null and void and without international legal effect'. UNSC Res 497 (17 December 1981) UN Doc S/RES/497. See also UNGA Res 67/25 (30 November 2012) UN Doc A/RES/67/25.

12 UNGA Res 2253 (4 July 1967) UN Doc A/RES/2253 (ES-V), paras 1-2.

13 UNGA Res 2254 (14 July 1967) UN Doc A/RES/2254 (ES-V), para 2.

14 See especially UN Human Rights Council (Falk), 'Report of the Special Rapporteur on the situation of human rights in the Palestinian territories occupied since 1967' (13 January 2014) UN Doc A/HRC/25/67, paras 33-38. 
position is that its exercise of jurisdiction over East Jerusalem is in accordance with international law. ${ }^{15}$

In addition to the above examples of territories that can be considered annexed either by virtue of a State's attempted extension of its laws and jurisdiction over a territory or a purported alteration in the territory's international status, there have been numerous historic examples of annexed territories, including Kuwait, ${ }^{16}$ East Timor ${ }^{17}$ and the Baltic States. ${ }^{18}$

All cases of annexation present common legal problems. For present purposes, the principal questions that arise are whether the annexing State's treaties succeed - to any extent - to the de jure sovereign's treaties; to what extent they might apply extraterritorially in the annexed territory by virtue of their object and purpose or provisions; and what the status of the dispossessed State's treaties in the territory is. These questions, as the current example of the Crimea and Sevastopol demonstrates, are of contemporary importance, though they are also of general concern.

\section{STATE SUCCESSION AND THE TERRITORIAL APPLICATION OF TREATIES}

'State succession' is not an intuitively easy term to grasp in the circumstances under consideration, which concern two continuing States. Indeed, the term is not fitting in the event of a forcible acquisition of territory by one State from another, because no legal 'succession' under international law occurs in these circumstances. Yet even in lawful situations the term may be ill-chosen in connection with a transfer of territory. The International Law Commission (ILC) itself, in its commentary to what is now Article 15 VCST, noted that the case of moving boundaries arguably did not fit within the meaning of 'State succession', but rather was a straightforward application of the territorial principle in Article 29 VCLT. ${ }^{19}$ According to Article 2(1)(b) VCST, "succession of States" means the replacement of one State by another in the responsibility for the international relations of territory'. ${ }^{20}$

The Conference on Yugoslavia Arbitration Committee in its Opinion No 1 used this same definition to characterize State succession, but added: '[T]he phenomenon of State succession is governed by the principles of international law, from which the Vienna Conventions of August 23rd, 1978

15 See Israel Ministry of Foreign Affairs, 'The Status of Jerusalem' (March 1999) <http://mfa. gov.i1/MFA/MFA-Archive/1999/Pages/The\%20Status\%20of\%20Jerusalem.aspx>.

16 See UNSC Res 662 (9 August 1990) UN Doc S/RES/662, paras 1-2.

17 See UNSC Res 384 (22 December 1975) UN Doc S/RES/384, paras 1-2; UNSC Res 389 (22 April 1976) UN Doc S/RES/389, paras 1-2.

18 See 'Baltic Republics: Statement by the Acting Secretary of State, Mr. Welles' (1940) 3 Department of State Bulletin 48.

19 The provisions of the VCLT do not apply to matters of State succession, by virtue of art 73 VCLT.

${ }^{20}$ VCST, art 2(1)(b). 
and April 8th, 1983 have drawn inspiration.'21 Indeed, the term 'State succession' as used in these instruments describes a transfer of international responsibility in respect of territory in conformity with international law. Opinion No 1 further specified: '[T]he peremptory norms of general international law and, in particular, respect for the fundamental rights of the individual and the rights of peoples and minorities, are binding on all parties to the succession.' 22

None of the relevant instruments contains a working definition of 'territory'. These instruments appear to assume, however, that the term refers to territory over which the state's legal title extends. The limitation of the VCST to cases of lawful succession by virtue of Article 6 corroborates this reading, as does the ILC's 1966 commentary to what is now Article 29 VCLT. ${ }^{23}$ Indeed, the commentary to what became Article 29 strongly suggests that extraterritorial application falls outside the scope of this provision. Similarly, where a bilateral or multilateral treaty contains a clause specifying its applicability with respect to the 'territory' of one of the contracting states, the use of this term again appears to assume, in line with accepted principles of interpretation under the VCLT and general international law, that the reference is to territory to which the State can claim legal title. At the very least it is a defensible position that a term's preferred interpretation should be one that does not putatively allow or require conduct, or recognize situations, in conflict with other rules of international law. This is particularly so where that other rule is one as significant as the prohibition of forcible acquisition of territory.

However, borderline cases with respect to the meaning of 'territory' will arise in practice, for example where unlawful occupation, coupled with a claim to sovereignty, endures for so significant a period of time that a transfer of territory may come to be regarded as a fait accompli by other States. For a long time Indonesia's occupation of East Timor provided an illustration. Australia's position, for example, was that East Timor had become part of Indonesian territory through the continuous and effective exercise of attributes of sovereignty. ${ }^{24}$ In such circumstances, the meaning of 'territory'

21 Conference on Yugoslavia Arbitration Committee, Opinion No 1 [1992] ILM 1494, para 1(e). The treaty of 8 April 1983 is the Vienna Convention on Succession of States in Respect of State Property, Archives and Debts (concluded 8 April 1983, not yet in force). See also Opinion No 9 [1992] ILM 1523, para 2. On treatments of State succession by the International Court of Justice, albeit in different contexts, see Gabčikovo-Nagymaros Project (Hungary/Slovakia) [1997] ICJ 7, paras 123-124; Application of the Convention on the Prevention and Punishment of the Crime of Genocide, Preliminary Objections (Bosnia and Herzegovina v Serbia and Montenegro) [1996] ICJ 595, paras 17-26.

${ }_{22}$ Conference on Yugoslavia Arbitration Committee, Opinion No 1 (n 21) para 1(e). See further ibid at para 3: '[I]t is incumbent upon the Republics to settle such problems of State succession as may arise from this process in keeping with the principles and rules of international law, with particular regard for human rights and the rights of peoples and minorities.'

${ }^{23}$ ILC Yearbook 1966, vol II, 213 (draft article 25 commentary).

${ }^{24}$ Comm Rec 1978, 25-26, reprinted in 'Recognition: Australian Practice in International Law' (1978-80) 8 AYBIL 279. 
as an element of an international legal rule, or where the word appears in a treaty provision, is less clear.

A further distinction is necessary between the general territorial application of treaties, the specific reference to territory as a trigger to the applicability of treaty obligations, and treaty obligations that pertain materially to specific territory. The first category reflects the general rule and cuts across all treaty law. Extradition treaties, double taxation treaties and investment treaties, for example, illustrate the second category. For instance, only in the event of an investment made in a certain territory are a party's obligations with respect to the standards of treatment of that investment under an investment treaty typically triggered. The third category comprises instruments that provide for obligations, among others, the very subject matter of which is a specific territory. ${ }^{25}$ The 1959 Antarctic Treaty and the 1920 Svalbard Treaty offer examples. $^{26}$

\section{THE MOVING TREATY-FRONTIERS RULE UNDER INTERNATIONAL LAW}

\section{A. The Position under the 1978 VCST and under the 1969 VCLT}

Article 29 VCLT and Article 15 VCST provide a starting point, though not an end point, for an inquiry into the legal position under consideration here. They provide a starting point because they offer a statement of the moving treatyfrontiers rule under general international law. They do not constitute an end point, however, because this moving treaty-frontiers rule does not extend to territory over which a State party cannot claim title, such as annexed territory. A separate, supplementary rule, if any, would regulate the applicability of a treaty to such territory.

Article 29 VCLT reflects an important principle of international law and provides: 'Unless a different intention appears from the treaty or is otherwise established, a treaty is binding upon each party in respect of its entire territory.' Article 15 VCST extends the moving treaty-frontiers rule, as reflected in Article 29 VCLT, to cases of State succession involving the transfer of territory from one State to another, with certain modifications for the context of succession. This article specifically provides that when part of a State's territory, or a territory for the international relations of which a State is responsible, becomes part of another State's territory, the treaties of the predecessor State cease to be in force from the date of the succession. It further provides that the successor State's treaties come into force with

\footnotetext{
${ }^{25}$ S Karagiannis, 'The Territorial Application of Treaties' in DB Hollis (ed), The Oxford Guide to Treaties (OUP 2012) 317.

26 The Antarctic Treaty (signed 1 December 1959, entered into force 23 June 1961) 402 UNTS 71; Treaty Concerning the Archipelago of Spitsbergen (signed 9 February 1920, entered into force 14 August 1925). See ILC (Waldock), 'Third Report on the Law of Treaties' (1964) in ILC Yearbook 1964, vol II, 12.
} 
respect to that territory from the date of succession, 'unless it appears from the treaty or is otherwise established that the application of the treaty to that territory would be incompatible with the object and purpose of the treaty or would radically change the conditions for its operation'. ${ }^{27}$ These dual limitations render Article 15 VCST somewhat narrower than Article 29 VCLT. That is not surprising, since one of Article 29 VCLT's main purposes was, among other things, to address the application of treaties as between the metropolitan state and its overseas territories, ${ }^{28}$ whereas Article 15 VCST addresses the moving treaty-frontiers rule in the narrower context of State succession involving the transfer of territory in conformity with international law.

The ILC's commentary to Article 15 (formerly draft article 14) is instructive. The Commission defined the 'moving treaty-frontiers' rule in these terms:

\begin{abstract}
Shortly stated, the moving treaty-frontiers rule means that, on a territory's undergoing a change of sovereignty, it passes automatically out of the treaty régime of the predecessor sovereign into the treaty régime of the successor sovereign. It thus has two aspects, one positive and the other negative. The positive aspect is that the treaties of the successor State begin automatically to apply in respect of the territory in question as from the date of the succession. The negative aspect is that the treaties of the predecessor State, in turn, cease automatically to apply in respect of such territory as from that date. ${ }^{29}$
\end{abstract}

The ILC in this passage confirmed that the moving treaty-frontiers rule reflected in Article 29 VCLT provided the rationale for the rule in Article 15 VCST. $^{30}$ These provisions reflect the default rule that governs the territorial application of a treaty, unless otherwise established. ${ }^{31}$ Finally, the commentary to Article 15 notes with respect to the rule in Article 29 VCLT: 'This means generally that at any given time a State is bound by a treaty in respect of any territory of which it is sovereign, but is equally not bound in respect of territory which it no longer holds.' Yet while the moving treaty-frontiers rule requires that prima facie a treaty applies to the entirety of a State's territory, the rule does not necessarily imply that a treaty applies only in a party's territory.

The VCST contains a blanket limitation clause in the form of Article 6. This article provides that the 'Convention applies only to the effects of a succession of States occurring in conformity with international law and, in particular, the principles of international law embodied in the Charter of the United Nations.' 32

27 VCST, art 15.

28 See UN Office of Legal Affairs, Summary of Practice of the Secretary-General as Depositary of Multilateral Treaties (1994) 83-5, <https://treaties.un.org/doc/source/publications/practice/ summary_english.pdf $>$. See further A Aust, Modern Treaty Law and Practice (3rd edn, CUP 2013) 178-90.

29 ILC Yearbook1974, vol II (Pt Two), 208 (draft article 14 commentary). $\quad 30$ ibid.

31 See B Stern, 'La succession d'états' (1996) Recueil des Cours 134-5.

32 The ILC's commentary on the draft article notes that certain 'members [of the ILC] ... were of the opinion that, in regard particularly to transfers of territory, it was desirable to underline that only transfers occurring in conformity with international law would fall within the concept of "succession of States" for the purpose of the present articles. ... [T] he commission decided to include among the 
The case of unlawfully annexed territory is squarely captured by this limitation clause and consequently lies outside the scope of the 1978 Convention. In fact, this is the case ex hypothesi. Thus the application of Article 15 as a treaty provision in a situation arising out of the annexation of territory, where both parties to the dispute are also parties to the VCST, is not possible as a consequence of Article 6. The VCLT, by contrast, contains no equivalent express limitation, but the ILC's commentary strongly suggests that the applicability of Article 29 is limited to de jure territory.

The Commission's commentary to the Draft articles on Succession of States in Respect of Treaties further makes it clear that the Convention, and Article 15 in particular, only apply to lawful changes of sovereignty. The commentary notes in this respect:

This article [draft article 14, viz Article 15 VCST], like the draft articles as a whole, has to be read in conjunction with article 6 which limits the present articles to lawful situations and with the saving clause of articles 38 and 39 concerning cases of military occupation, etc. Article 14 is limited to normal changes in the sovereignty or in the responsibility for the international relations of a territory. ... As to Article 6, although the limitation to lawful situations applies throughout the draft articles, some members of the Commission considered it to be of particular importance in the present connexion. ${ }^{33}$

As far as the practical operation of the moving treaty-frontiers rule is concerned, the Commission in its commentary noted: ' $[\mathrm{I}] \mathrm{n}$ most cases the moving of the treaty frontier is an automatic process. The change in the treaty régime applied to the territory is rather the natural consequence of its having become part of the territory of the State now responsible for its international relations. ${ }^{34}$ The term 'responsible for its international relations' - though outdated - again connotes an internationally lawful territorial arrangement.

However, the presence of this limitation clause in the VCST does not necessarily have a bearing on any equivalent customary status of the moving treaty-frontier rule reflected in Article 15 VCST and Article 29 VCLT. There could, at least conceivably and as discussed further below, be room under general international law for a separate rule that allows a treaty's territorial application in unlawfully acquired territory. The justification for such a rule could find a possible basis in the protection of natural and legal persons' rights. Such a rule, however, could only apply where the treaty does not define the territory over which it is applicable as such territory over which a party exercises sovereign rights or jurisdiction in accordance with international law, as some treaties do. To find that such a treaty applied in annexed territory, notwithstanding such a provision, is to render these words meaningless.

general articles a provision safeguarding the question of the lawfulness of the succession of States dealt with in the present articles.'

33 ILC Yearbook 1974, vol II (Pt Two), 209 (draft article 14 commentary). $\quad{ }^{34}$ ibid 210. 


\section{B. Recent Practice on Moving Treaty-Frontiers and the Rule's Status under Customary International Law}

Recent arbitral and judicial practice offers a helpful discussion of the status of the moving treaty-frontiers rule under customary international law. In Sanum Investments Ltd v The Government of the Lao People's Democratic Republic, the arbitral tribunal applied the rule in its award on jurisdiction. ${ }^{35}$ That dispute arose in connection with certain investments made by Sanum Investments Ltd, a company incorporated in the Macau Special Administrative Region of China (Macau SAR), in the Lao People's Democratic Republic. The claimant alleged breaches of various host-state obligations under the People's Republic of China-Laos bilateral investment treaty (PRC-Laos BIT), and the jurisdictional question that arose was whether the PRC-Laos BIT extended territorially to the Macau SAR. Macau had previously been under the administration of Portugal and sovereignty was transferred to the PRC in 1999. ${ }^{36}$ The transfer of sovereignty in that case was lawful and executed by treaty, ${ }^{37}$ and the dispute did not give rise to the questions of unlawfulness presently under consideration in the context of annexation. Nevertheless, the decision is instructive. The tribunal concluded that the PRC-Laos BIT extended to the Macau SAR by virtue of the moving treaty-frontiers rule under customary international law.

The award in Sanum offers a general statement of moving treaty-frontiers status as a rule of customary international law. ${ }^{38}$ The tribunal noted: 'Both Article 29 of the VCLT and Article 15 of the VCST are rules of customary international law. ... [T] he two rules exist side-by-side, Article 15 being the corollary of Article 29 and Article 29 being a consequence of Article 15.' It further noted that it was 'undisputed by the Parties that Article 29 in its entirety has the force of binding customary international law'39 and that 'the principle of territorial extension of the State's legal order embodied in Article 29 [VCLT] applies, unless otherwise indicated'. ${ }^{40}$ The tribunal also observed: 'The Tribunal first notes that the ILC, in its 1974 Commentary on Draft Article 14 (which became Article 15) of the VCST, is explicit that the "moving treaty frontiers" rule was a pre-existing customary rule. ${ }^{41}$

Further, the tribunal in Sanum stated with respect to the moving treaty-frontiers rule and the exceptions under Article 15 VCST: 'Indeed, automatic succession

35 Sanum Investments Ltd v The Government of the Lao People's Democratic Republic, Award on Jurisdiction, 13 December 2013, UNCITRAL, PCA Case No 2013-13.

36 See Joint Declaration of the Government of the Portuguese Republic and the Government of the People's Republic of China on the Question of Macao (with annexes) (People's Republic of China-Portuguese Republic) (signed 13 April 1987, entered into force 15 January 1988) 1498 UNTS 228.

38 Sanum (n 35) paras 220-221.

39 ibid, para 220. The tribunal reached this conclusion in part on the basis that there was little disagreement between the parties this point, and that consequently it did not need to develop upon the status of this rule under customary international law in detail, though it did offer some discussion.

40 ibid, para 270.

41 ibid, para 222. 
applies unless it appears from the treaty itself or is otherwise established that such a result would not be appropriate for one of two reasons: either because such succession would be incompatible with the object and the purpose of the treaty or because it would radically change the conditions of its operation. ${ }^{\prime 2}$

In an interesting subsequent development in this dispute, the High Court of Singapore held in Government of the Lao People's Democratic Republic $v$ Sanum Investments Ltd, primarily on the basis of fresh evidence ${ }^{43}$ in the form of two governmental letters that in its view constituted a 'subsequent agreement' within the meaning of Article 31(3)(a) VCLT, that the parties had intended for the PRC-Laos BIT not to extend to the Macau SAR. ${ }^{44}$ The parties in the Singapore proceedings also 'agreed that both [Article 29 VCLT and Article 15 VCST] are rules of customary international law' ${ }^{45}$ The High Court of Singapore noted that 'the PRC-Laos BIT is prima facie applicable to the entire territories of Laos and the PRC which indisputably includes Macau', ${ }^{46}$ but found the Article 31(3)(a) exception on the basis that it was 'otherwise established' within the meaning of Article 29 VCLT and Article 15 VCST that the parties did not intend it to be in force with respect to the Macau SAR. ${ }^{47}$ The decision still stands as authority, however, for the status of the moving treaty-frontiers rule as part of customary international law.

Further, in addition to the ILC, the tribunal in Sanum, the High Court of Singapore, academic commentary and the work of learned bodies, ${ }^{48}$ the UN Office of Legal Affairs also takes the position that the rule reflected in Article 15 VCST and Article 29 VCLT is one of general application under customary international law. According to the Handbook of Final Clauses prepared by the Treaty Section of the UN Office of Legal Affairs, "[ $t$ ]he basic principle is that a treaty will be binding upon a State in respect to its entire territory'. ${ }^{49}$ It notes that Article 29 codified customary international law. ${ }^{50}$ The Handbook also observes that '[i]n principle, the absence of a territorial clause obliges a State to apply the treaty to its entire territory'. ${ }^{51}$

In practice, the application of the moving treaty-frontiers rule can be modified by a negotiated agreement, and often is, so as to achieve an application of the rule tailored to the specific circumstances of the case. The Treaty of Unity between the Federal Republic of Germany and the German Democratic

\footnotetext{
42 ibid, para 230 (emphasis in original).

43 Government of the Lao People's Democratic Republic v Sanum Investments Ltd [2015] SGHC 15, para 67

46 ibid, para 62. 44 ibid, para 70 . See also paras 77-78.

45 ibid, para 60.

. For academic commentary, see Karagiannis (n 25) 306-9; G Hafner and G Novak, 'State Succession in Respect of Treaties' in Hollis (n 25) 397. For expert body commentary, see International Law Association, 'Aspects of the Law of State Succession: Draft Final Report' (2008) 5 .

${ }^{49}$ UN Office of Legal Affairs, Final Clauses of Multilateral Treaties: Handbook (2003) 78 $<$ https://treaties.un.org/doc/source/publications/FC/English.pdf $>$.

50 ibid 81.

51 ibid. However, a provision for the optional extension of a treaty's territorial application typically only allows a party to extend a treaty to a territory, such as a dependency, for the international relations of which it is responsible under international law.
} 
Republic provides an example of a negotiated application of the moving treatyfrontiers rule and an express application of the rule in a treaty. ${ }^{52}$ Article 11 of that treaty provides that the parties agree that treaties and agreements to which the Federal Republic is a party and that rights and obligations arising under them shall, in general though with certain limitations, apply to the territories of Brandenburg, Mecklenburg-Vorpommern, Sachsen, Sachsen-Anhalt, Thüringen and Berlin, as identified in Article 3.53 Similarly, the moving treaty-frontiers rule only applied, if at all, in modified form and on the basis of bilateral agreements in the case of Hong Kong. ${ }^{54}$ In most instances, however, and in particular in those involving an unlawful acquisition of territory, a negotiated position will be unlikely. In such circumstances a clear statement of the position under general international law becomes all the more important.

\section{ANNEXATION OF TERRITORY UNDER INTERNATIONAL LAW}

\section{A. Terminology and Territorial Status}

The term 'annexation' in international law for present purposes describes the domestic legal act of a State purporting to extend sovereignty over a piece of territory over which it has gained effective control through non-consensual, forcible means. This act can, for example, take the form of an express claim to legal title, an attempted extension of a State's laws and jurisdiction over the controlled territory, or of any other attempted alteration of the territory's international legal status in an effort to incorporate it into the State's territory. Where a transfer of territory occurs with the consent of the ceding State, it is more common and appropriate to speak of a 'cession' of territory. ${ }^{55}$ It is the forcible and non-consensual character of annexation that renders it different from cession of territory. ${ }^{56}$

The focus here is on one State's annexation of a part of the territory under the sovereignty of another State, rather than the annexation of the entire territory of

\footnotetext{
52 This example, however, can also be characterized as the incorporation of one State into another.

53 Treaty on the Unification of Germany (signed 31 August 1990, entered into force 29 September 1991) [1991] 30 ILM 463, art 11. See further Gamarra (n 1) 402-6 and Aust (n 28) 326-7.

54 See eg 'Memorandum to All Department and Agency Executive Secretaries: Legal Status of Hong Kong upon Reversion to the People's Republic of China' (undated) 4, <http://www.state.gov/ documents/organization/65788.pdf >: 'Given the unique circumstances of Hong Kong, however, there will be exceptions to the Moving Treaty Frontier rule with respect to certain agreements between the US and Hong Kong and also agreements between the US and the PRC.' See generally R Mushkat, 'Hong Kong and Succession of Treaties' (1997) 46 ICLQ 192 (arguing that the moving treaty-frontiers rule was inapplicable in the case of Hong Kong because of the territory's highly autonomous status). See further Aust (n 28) 190-1, 336.

55 See eg J Crawford (ed), Brownlie's Principles of Public International Law (8th edn, OUP 2012) 226-8; Hafner and Novak (n 48) 404-5; Venice Commission, Opinion no 763/2014 (n 3) paras $17-18$.

56 See Hafner and Novak (n 48) 405.
} 
that second State and its de facto incorporation into the first State. 'Annexed territory' describes the territory that is subject to an act of annexation of the variety presently under consideration. The unqualified terms 'annexed' and 'annexation', as used in this article, by themselves already connote unlawfulness.

However, in contrast to military occupation, which involves an acknowledgment that the occupying State is not claiming the occupied territory as part of its territory, annexation involves the additional step of claiming sovereignty over the territory. Where the annexing State makes such a claim, extends its laws or jurisdiction to the territory or otherwise attempts to incorporate the territory by altering its international legal status, the annexed territory might form part of the annexing State's territory as a matter of its domestic law, but it would not form part of the annexing State's territory under international law.

Since annexation of territory under international law is unlawful, the purported annexation produces no international legal effect with respect to de jure sovereignty over the territory, neither towards the injured State nor towards third States. On the contrary, all States have an obligation under general international law not to recognize the lawfulness of the acquisition of such territory or any claim to sovereignty over it. ${ }^{57}$

Security Council resolution 662 (1990) with respect to the situation in Kuwait offers a well-known example of the characterization of a particular territorial situation as an 'annexation' ${ }^{58}$ In that instrument, the Council decided 'that annexation of Kuwait by Iraq under any form and whatever pretext has no legal validity, and is considered null and void'. ${ }^{59}$ In paragraph 2 of that resolution the Council called 'upon all States, international organizations and specialized agencies not to recognize that annexation, and to refrain from any action or dealing that might be interpreted as an indirect recognition of the annexation'.

In practice, annexation may, for example, take the form of a claim to sovereignty following a military occupation of the territory. Neither the claim to sovereignty nor, in fact, the occupation itself changes the status of the territory under international law. In particular, according to the 1977 First Additional Protocol, the application of the 1949 Geneva Conventions in no way alters the territory's status: 'Neither the occupation of a territory nor the application of the Conventions and this Protocol shall affect the legal status of the territory in question. ${ }^{60}$ In practice, 'annexed territory' may for the

${ }^{57}$ ILC, Articles on the Responsibility of States for Internationally Wrongful Acts (2001) in ILC Yearbook 2001, vol II (Pt Two), arts 40 and 41 (ARSIWA).

${ }_{58}$ UNSC Res 662 (9 August 1990) UN Doc S/RES/662.

59 ibid, para 1. On the unlawfulness of Iraq's annexation of Kuwait, see also Kuwait Airways Corp v Iraq Airways Co (Nos 4 \& 5) [2002] 2 AC 883, 1099 and 1109.

60 Protocol Additional to the Geneva Conventions of 12 August 1949, and Relating to the Protection of Victims of International Armed Conflicts (Protocol I) (adopted 8 June 1977, entered into force 7 December 1978) 1125 UNTS 3. 
purposes of its international legal status simply be territory under military occupation, though the state of occupation depends, according to Article 42 of the 1907 Hague Regulations concerning the Laws and Customs of War on Land (1907 Hague Regulations), on the actual authority exercised by the army of the occupying power. ${ }^{61}$ It is conceivable that not all annexed territory necessarily remains territory under occupation. Where territory is under occupation, the obligations of an occupying power find their basis primarily in certain provisions of the 1907 Hague Regulations ${ }^{62}$ and the 1949 Geneva Convention (IV) relative to the Protection of Civilian Persons in Time of War (GCIV). ${ }^{63}$ The law of occupation may indeed form a lex specialis, assuming the annexed territory is territory under occupation within the above meaning, which renders the general law of treaties and State succession with respect to treaties inapplicable for the duration of the occupation. This lex specialis may form a basis, independently of the law of treaties and State succession in respect of treaties, for suspending the applicability of the de jure sovereign's treaties in the occupied territory and applying the annexing State's treaties, at least to a limited extent.

Pursuant to Article 40 VCST ' $[\mathrm{t}] \mathrm{h}$. provisions of the present Convention shall not prejudge any question that may arise in regard to a treaty from the military occupation of a territory'. Similarly, Article 73 VCLT provides that ' $[t]$ he provisions of the present Convention shall not prejudge any question that may arise in regard to a treaty from ... the outbreak of hostilities between States'. These provisions also lend support to the claim that the law of State succession in respect of treaties and the law of treaties under general international law may not necessarily fully govern the territorial applicability of treaties in territory under occupation, and that there may be room for special rules in such settings, as discussed below.

The case for the succession of the annexing or occupying State's treaties in respect of such territory becomes ever more compelling, to the extent permitted by their provisions, as the annexation or occupation endures across time, and in particular where no return to the status quo ante is realistically in sight.

\section{B. Legal Consequences of Annexation under International Instruments and General International Law}

It is more common for international instruments to provide that the acquisition of territory through the threat or use of force shall not be recognized as lawful

61 See Convention (IV) respecting the Laws and Customs of War on Land and its annex: Regulations concerning the Laws and Customs of War on Land (adopted 18 October 1907, entered into force 26 January 1910) 205 CTS 277, art 42. ${ }^{62}$ See especially arts 42-56.

${ }^{63}$ Geneva Convention Relative to the Protection of Civilian Persons in Time of War (adopted 12 August 1949, entered into force 21 October 1950) 75 UNTS 287. 
than to provide outright that annexation is unlawful. ${ }^{64}$ Forcible acquisition of territory would typically already be covered by the prohibition of the use of force against the political independence and territorial integrity of another State, coupled with the principle of non-intervention in another State's domestic affairs.

Non-recognition is a decentralized enforcement mechanism. ${ }^{65}$ The obligation of non-recognition, specifically with respect to a territorial acquisition resulting from a use of force in breach of Article 2(4) of the UN Charter, is reflected in the General Assembly's 1970 Declaration on Principles of International Law Concerning Friendly Relations and Cooperation among States in accordance with the Charter of the United Nations. ${ }^{66}$ According to the Declaration, "no territorial acquisition resulting from the threat or use of force shall be recognized as legal'. ${ }^{67}$ According to the International Court of Justice (ICJ) in its 1986 judgment on the merits in Military and Paramilitary Activities in and against Nicaragua, the 1970 Declaration on Friendly Relations represents a statement of the position under customary international law on this point. ${ }^{68}$

The Charter of the Organization of American States contains a similar provision. Article 21 of that instrument provides that ' $[\mathrm{n}] \mathrm{o}$ territorial acquisitions or special advantages obtained either by force or by other means of coercion shall be recognized' ${ }^{69}$ Further, Article 5(3) of the General Assembly's Definition of Aggression provides that '[n]o territorial acquisition or special advantage resulting from aggression is or shall be recognized as lawful' ${ }^{70}$ Opinion No 3 of the Conference on Yugoslavia Arbitration Commission noted that '[a]ccording to a well-established principle of international law the alteration of existing frontiers or boundaries by force is not capable of producing any legal effect'. ${ }^{71}$ Article 11 of the

\footnotetext{
${ }^{64}$ In the past, annexations or forced cessions of territory were generally accepted. In the wake of a conquest, for example, the victor State would typically impose a treaty of cession on the defeated State. See eg Treaty of Peace, Friendship, Limits and Settlement between Mexico and the United States, signed at Guadelupe Hidalgo (signed 2 February 1848), 102 CTS 29, art 5.

${ }_{65}$ ARSIWA, art 41. The International Court of Justice recognized the obligations of nonrecognition and non-assistance in Legal Consequences of the Construction of a Wall in the Occupied Palestinian Territories [2004] ICJ 136, para 159.

${ }_{66}$ Declaration on Principles of International Law Concerning Friendly Relations and Cooperation among States in accordance with the Charter of the United Nations, UNGA Res 2625 (XXV) (24 October 1970) UN Doc A/RES/25/2625, art 1.

67 ibid.

${ }^{68}$ See Military and Paramilitary Activities in and against Nicaragua (Nicaragua $v$ United States of America) [1986] ICJ 14, para 188.

${ }_{69}$ Charter of the Organization of American States (signed 30 April 1948, entered into force 13 December 1951) 119 UNTS 47, art 21.

70 Definition of Aggression, UNGA Res 3314 (XXIX) (14 December 1974) UN Doc A/RES/29/ 3314.

${ }^{71}$ Conference on Yugoslavia Arbitration Commission, Opinion No 3 [1992] 31 ILM 1499, para 2.
} 
1933 Convention on Rights and Duties of States provided for a "precise obligation not to recognize territorial acquisitions or special advantages which have been obtained by force' ${ }^{72}$ The obligation not to recognize a legal situation brought about by the serious breach of an obligation under a peremptory norm is reflected in Article 41 of the Articles on the Responsibility of States for Internationally Wrongful Acts. In fact, so well established is the unlawfulness of the forcible and non-consensual acquisition of territory in international law that it is an uncontroversial proposition. More uncertain are the precise effects, if any, on other rules of international law such as treaty succession and State responsibility of the de facto exercise of sovereign powers over an annexed piece of territory.

In general, States are entitled in response to an unlawful acquisition of territory to make this determination of unlawfulness unilaterally and to act upon it through the obligations of collective non-recognition and nonassistance, and possibly, though more controversially, through third-party countermeasures. ${ }^{73}$ Non-recognition and non-assistance are self-help enforcement measures. Such measures are often necessary, because it lies in the highly sensitive and political character of such situations that the annexation of territory will virtually never be the subject of third-party adjudication by the International Court of Justice or an ad hoc inter-State arbitral tribunal. There is no need for a Security Council determination under Chapter VII of the Charter that the annexation was unlawful for these obligations to arise. ${ }^{74}$ Given this legal position, the central question is what the effects of an unlawful annexation of territory are for the territorial application of treaties in the territory.

\footnotetext{
72 Convention on the Rights and Duties of States (signed 26 December 1933, entered into force 26 December 1934) 165 LNTS 19.

73 For a statement regarding the availability of third-party countermeasures, see ARSIWA, art 54. However, this ambiguous provision must be read in conjunction with art 22 . According to art 22, the wrongfulness of an act is precluded if that act is a countermeasure in accordance with Chapter II of Part Three ('Countermeasures') of the Articles. In other words, the wrongfulness of the act is precluded to the extent it falls within the meaning of a 'countermeasure'. Art 54, by contrast, speaks only of 'lawful measures'. See generally M Dawidowicz, Public Law Enforcement without Public Law Safeguards? An Analysis of State Practice on Third-Party Countermeasures and their Relationship to the Security Council' [2006] 77 BYBIL 333; M Dawidowicz, 'Thirdparty countermeasures: Observations on a controversial concept' in C Chinkin and F Baetens (eds), Sovereignty, Statehood and State Responsibility: Essays in Honour of James Crawford (2015) 340 .

74 See East Timor (Portugal v Australia) [1995] ICJ 90, 262-3 (Judge Skubiszewski diss op, para 125). However, an obligation of non-recognition with respect to the lawfulness of a situation can also follow from a Security Council finding of an unlawful situation in accordance with arts 24 and 25 of the Charter, or indeed from a finding of illegality by the International Court of Justice. See Legal Consequences of the Construction of a Wall (n 65) 216-17 (Judge Higgins sep op, para 38).
} 


\section{THE STATUS OF TREATIES IN ANNEXED TERRITORY}

A. Possible Application of the Annexing State's Treaties by Virtue of the Moving Treaty-Frontiers Rule in the Law of State Succession and the Law of Treaties

The first, and central, question is again one of assigning meaning to a term: what is the legal meaning of the unqualified term 'territory' in Article 15 VCST and Article 29 VCLT? The term 'territory' is not specifically defined in these provisions. According to the ILC's commentary on Article 29 VCLT (formerly draft article 25), "[t]he term "the entire territory of each party" is a comprehensive term designed to embrace all the land and appurtenant territorial waters and air space which constitute the territory of the State'. ${ }^{75}$

Neither Article 29 nor its commentary mentions territory over which a State exercises de facto authority, yet which is not legally part of that State's territory. However, the use of the term 'territory of each party' in Article 29 seems to reflect the understanding that only territory which is de jure part of a State is included. The same holds true for the term 'territory of another State' in Article 15 VCST. Here, too, the obvious implication is that the provision applies only to de jure territory. These unqualified provisions simply do not address a situation of extraterritorial application, though they do not exclude such a possibility. It would be straining the text to an impermissible extent to read into these provision an exception to the otherwise only de jure character of 'territory', since that term cannot by itself sustain a reading that includes annexed territory and, in fact, that is not what these provisions were designed for.

Absent a territorial application clause, and where the VCST and the VCLT do not apply, the customary equivalent to the rule reflected in Article 15 VCST and Article 29 VCLT applies by default. Here the scope for flexibility in territorial application may be slightly broader than where the treaty's application is expressly limited by reference to 'territory'. It is difficult to see though why the term 'territory' should have a broader meaning under customary international law than it does in Article 15 VCST, Article 29 VCLT, or a territorial application clause in a treaty. Under the default approach, a treaty could arguably apply with respect to territory that a State controls and over which it claims sovereignty, even if unlawfully. For example, the Netherlands Hoge Raad in a June 2015 decision dismissed an appeal against a lower court's decision under the Netherlands-Israel extradition agreement. The defendant had, in these proceedings, raised a jurisdictional objection in part on the basis that Israel had no jurisdiction to request extradition with respect to acts committed in East Jerusalem. The lower court noted that it was only competent to question the jurisdiction of the requesting court in Israel where it had a grave prima facie suspicion that jurisdiction was

75 ILC Yearbook 1966, vol II, 213 (draft article 25 commentary). 
lacking, and found that no such suspicion arose here. The Attorney-General agreed and further pointed out that even if Israel had no jurisdiction under the territoriality principle there might be other heads of jurisdiction it could invoke. The Hoge Raad acknowledged this reasoning, and the defendant's jurisdictional objection consequently failed. ${ }^{76}$

A territory that a State controls and over which it claims sovereignty could conceivably include one that a State has forcibly acquired and annexed. The point to note, as the Singapore High Court did in Government of Laos $v$ Sanum, is that neither Article 29 VCLT nor Article 15 VCST is absolute. Both by their terms allow for departures from the default position on territorial application. Moreover, Articles $29 \mathrm{VCLT}$ and $15 \mathrm{VCST}$, and the rule of general international law they reflect, generate a presumption in favour of a treaty's application to a party's entire territory, but do not necessarily create a presumption that a treaty's application is limited to a party's territory. ${ }^{77}$

There are various bases on which a treaty can enjoy extraterritorial application, including possibly in annexed territory.

\section{B. Possible Application of the Annexing State's Treaties by Virtue of Their Object and Purpose}

A pertinent distinction, which may well in a given case follow from a treaty's object and purpose within the meaning of Article 31 VCLT, is between treaties purporting to govern State conduct generally, which are often but not necessarily multilateral, and those purporting to govern State conduct with respect to a particular territory. Human rights treaties offer an illustrative example of the first category.

Ben-Naftali and Shany argue that '[f]rom both a policy and a philosophical perspective, it is perfectly logical that human rights treaties embrace this broad concept [of jurisdiction] in determining their scope of application. Human rights law is intended to protect individuals from the improper exercise of governmental power. It is also designed to ensure that governments provide for the needs of individuals. ${ }^{78}$

For example, as the International Court of Justice noted in Legal Consequences of the Construction of a Wall in the Occupied Palestinian

\footnotetext{
76 Hoge Raad, case no 15/00891 (30 June 2015) <http://uitspraken.rechtspraak.nl/ inziendocument?id=ECLI:NL:HR:2015:1759> Rechtbank Noord-Holland, case no 15/860168-14 (12 February 2015) <http://uitspraken.rechtspraak.nl/inziendocument?id=ECLI:NL:RBNHO: 2015:949> Opinion of the Attorney-General (9 June 2015) <http://uitspraken.rechtspraak.nl/ inziendocument?id=ECLI:NL:PHR:2015:967>.

77 Certain authors challenge the suggestion that art 29 VCLT creates a presumption that a treaty's application is limited to a party's territory. See O Ben-Naftali and Y Shany, 'Living in Denial: The Application of Human Rights in the Occupied Territories' [2003-04] 37 Israel Law Review 66-67; M Milanović, Extraterritorial Application of Human Rights Treaties: Law, Principles, and Policy (OUP 2011) 12.

78 Ben-Naftali and Shany (n 77) 61.
} 
Territories, with reference to the International Covenant on Economic, Social and Cultural Rights (ICESCR): ${ }^{79}$

The International Covenant on Economic, Social and Cultural Rights contains no provision on its scope of application. This may be explicable by the fact that this Covenant guarantees rights which are essentially territorial. However, it is not to be excluded that it applies both to territories over which a State party has sovereignty and to those over which that State exercises territorial jurisdiction. ${ }^{80}$

The Court added, in a significant passage for present purposes:

[The Court] would also observe that the territories occupied by Israel have for over 37 years been subject to its territorial jurisdiction as the occupying Power. In the exercise of the powers available to it on this basis, Israel is bound by the provisions of the International Covenant on Economic, Social and Cultural Rights. ${ }^{81}$

In making these statements with respect to the ICESCR, however, an instrument that contains no clause concerning its geographic scope of application ${ }^{82}$ and is governed by the customary rule on moving treaty-frontiers, the ICJ accepted the position that a State could in certain circumstances be under an obligation to secure the rights under the ICESCR in occupied territory, by virtue of the type of individual rights in question and the character of the obligations it created for parties. ${ }^{83}$ Indeed, in its Order of 18 October 2008 in the case concerning the Application of the International Convention on the Elimination of all Forms of Racial Discrimination (Georgia v Russian Federation), the ICJ noted that the International Convention on the Elimination of all Forms of Racial Discrimination (CERD) contained no general territorial limitation clause, and that neither Article 2 nor 5-which Georgia invoked - was territorially limited. ${ }^{84}$ On this basis, the Court found that 'these provisions of CERD generally appear to apply, like other provisions of instruments of that nature, to the actions of a State party when it acts beyond its territory' .85

79 International Covenant on Economic, Social and Cultural Rights (adopted 16 December 1966, entered into force 3 January 1976) 993 UNTS 3.

80 Legal Consequences of the Construction of a Wall (n 65) para 112.

81 ibid. The Court also held, in para 113 of the advisory opinion, that the Convention on the Rights of the Child was applicable in the Occupied Palestinian Territory. cf MJ Dennis,

'Application of Human Rights Treaties Extraterritorially in Times of Armed Conflict and Military Occupation' (2005) 99 AJIL 127-8.

82 Note, however, that art 28 provides that the Covenant 'shall extend to all parts of federal States without any limitations or exceptions.'

83 See further F Coomans, 'The Extraterritorial Scope of the International Covenant on Economic, Social and Cultural Rights in the Work of the United Nations Committee on Economic, Social and Cultural Rights' [2011] HRLRev 13.

84 International Convention on the Elimination of All Forms of Racial Discrimination (opened for signature 7 March 1966, entered into force 4 January 1969) 660 UNTS 195.

${ }^{85}$ Application of the International Convention on the Elimination of all Forms of Racial Discrimination (Georgia v Russian Federation), Order of 15 October 2008 [2008] ICJ 353, para 
What is more, certain treaties create obligations the very purpose of which is to apply extraterritorially. This is particularly the case with respect to those obligations arising for a State by virtue of its military occupation of another State's territory in an international armed conflict. Treaties that apply extraterritorially notably include the 1949 Geneva Conventions and the 1907 Convention (IV) respecting the Laws and Customs of War on Land and its annex. For example, in General Assembly resolution 45/170 that body among other things 'condemn[ed] the Iraqi authorities and occupying forces for their serious violations of human rights against the Kuwaiti people and third-State nationals', ${ }^{86}$ and also 'affirm[ed] that the Geneva Convention relative to the Protection of Civilian Persons in Time of War, of 12 August 1949, applie[d] to Kuwait and that as a high contracting party to the Convention Iraq is bound to comply fully with all its terms ... . ${ }^{87}$ Security Council resolutions addressing the international legal status of East Jerusalem also affirm the continued applicability of the GCIV in this territory. ${ }^{88}$

At the same time, it is also important to acknowledge that certain treaty obligations, even those designed to protect the rights and interests of natural and legal persons and arising under multilateral treaties, may not easily lend themselves to extraterritorial application. ${ }^{89}$

The case for extraterritorial application of treaties is particularly compelling with respect to human rights treaties, even where they contain no territorial or jurisdictional application clause. This is because the object and purpose of those instruments includes the regulation of State conduct generally and in a territorially detached sense, as indicated in the Court's Order of 15 October 2008 in Application of the International Convention on the Elimination of all Forms of Racial Discrimination, wherever the act attributable to a State may occur. The object and purpose of those instruments go beyond merely regulating conduct specifically and exclusively on the territory of the State party in question.

As Meron notes: 'In view of the purposes and objects of human rights treaties, there is no a priori reason to limit a state's obligation to respect human rights to its national territory. ${ }^{90}$ He further explains:

109. See also M Gondek, The Reach of Human Rights in a Globalising World: Extraterritorial Application of Human Rights Treaties (Intersentia 2009) 212-213.

${ }^{86}$ UNGA Res 45/170 (18 December 1990) UN Doc A/RES/45/170, para 1.

87 ibid, para 2.

88 See especially UNSC Res 478 (20 August 1980) UN Doc S/RES/478, para 2 ("Affirms that the enactment of the "basic law" by Israel constitutes a violation of international law and does not affect the continued application of the Geneva Convention relative to the Protection of Civilian Persons in Time of War, of 12 August 1949, in the Palestinian and other Arab territories occupied since June 1967, including Jerusalem.’).

${ }^{89}$ See T Meron, 'Extraterritoriality of Human Rights Treaties' (1995) 89 AJIL 80.

90 ibid. 
Where agents of the state, whether military or civilian, exercise power and authority (jurisdiction, or de facto jurisdiction) over persons outside national territory, the presumption should be that the state's obligation to respect the pertinent human rights continues. That presumption could be rebutted only when the nature and the content of a particular right or treaty language suggest otherwise. $^{91}$

Under this approach, the treaty's 'frontiers' become a more nuanced concept. In such a case, a treaty would apply to a State's entire territory by default, but would not be limited to a party's de jure territory. Such a determination would be without prejudice, however, to the lawfulness of the exercise of authority over the territory and the question of title.

Yet it is not possible to say that as a matter of principle human rights treaties always apply extraterritorially, in whole or in part. There is no basis in international law for rendering the applicability of a rule dependent solely on the subject matter of a particular treaty or some of its provisions, or indeed for formulating rules that extend only to treaties that share a particular subject matter. The relevant factor is the treaty's object and purpose. More practically, no strict classification along these lines is possible, because the categories are not clean and treaties span different subject matter categories, rendering their object and purpose less readily identifiable. Examples include the Convention against Torture (CAT), ${ }^{92}$ the Convention on the Prevention and Punishment of the Crime of Genocide ${ }^{93}$ and the Convention relating to the Status of Refugees. ${ }^{94}$ Even the International Covenant on Civil and Political Rights $(\text { ICCPR })^{95}$ and the ICESCR span different categories of rights and obligations. None of these is only a 'human rights treaty' in the neat, narrow sense capable of constituting a discrete legal category that could become the subject of special treatment.

It would still remain unclear in such a situation as of which point in time the 'annexing' State's treaties begin to apply, as of which point in time the 'dispossessed' State's treaties cease to apply, and whether there was or is any period of overlap during which both States' treaty rights and obligations were or are in force concurrently. The answers are likely to be highly fact-specific. Even if the 'annexing' State's treaties apply with respect to the territory, the principle of non-retroactivity of treaties reflected in Article 28 VCLT would still govern, absent provisions to the contrary, for example with respect to relevant events in

\footnotetext{
91 ibid 81.

92 Convention against Torture and Other Cruel, Inhuman or Degrading Treatment or Punishment (adopted 10 December 1984, entered into force 26 June 1987) 1465 UNTS 85.

93 Convention on the Prevention and Punishment of the Crime of Genocide (adopted 9 December 1948, entered into force 12 January 1951) 78 UNTS 277.

94 Convention relating to the Status of Refugees (opened for signature 28 July 1951, entered into force 22 April 1954) 189 UNTS 137.

95 International Covenant on Civil and Political Rights (adopted 16 December 1966, entered into force 23 March 1976) 999 UNTS 171.
} 
the territory. This can raise questions ratione temporis in the event of an alleged breach of an international legal obligation on the part of the annexing or injured State. Where a treaty establishes dispute resolution procedures, the dispute resolution body's jurisdiction ratione temporis may come into question.

One need only consider the alternative hypothetical in annexed territory to realize its absurdity. In the alternative scenario, the annexing State's treaty obligations would not apply, yet at the same time the dispossessed State could likely plead the non-attribution of a relevant act to it for the purposes of responsibility, ${ }^{96}$ or could invoke a circumstance precluding wrongfulness, with the result that effectively no treaty protections remain in place. The position is particularly acute with respect to treaties for the protection of individual rights, the object and purpose of which is to regulate the parties' conduct generally rather than in a territorially limited sense. Something has gone amiss if an individual were not legally in a position to invoke a treatybased right under either instrument even on the strength of an otherwise wellfounded claim, simply by virtue of a strict interpretation of the general rule reflected in Article 15 VCST and Article 29 VCLT. It seems an intuitively implausible conclusion that this territory would become a legal vacuum for the purposes of treaty commitments and protections.

Again, however, the annexing State may in reality indeed argue precisely that its treaties apply in the territory, as part of its legal claim to sovereignty over the territory, and it may be other treaty parties or third States who must in first instance adopt a position on these questions. In practice, the annexing State's claim to sovereignty over the territory in question may even amount to a declaration with preclusionary effect, and it may not be open to the annexing State at the same time to take the position that treaties to which it is a party have no territorial application in the territory. ${ }^{97}$ A preclusion argument of this variety would be particularly persuasive where the annexing State seeks to deny the territorial applicability of a treaty in the annexed territory in proceedings before an international court or tribunal.

\section{Possible Application of the Annexing State's Treaties by Virtue of a Treaty Provision}

Certain treaties can apply extraterritorially as a result of their provisions. Like many difficult questions in international law involving the application of treaties, the present one can, depending on the instrument's text, involve little more than the interpretation of its relevant provisions.

96 See generally ARSIWA, arts 4-11.

97 A State's constitution can further support this argument. See eg Constitution of Russian Federation, art 4(1): 'The sovereignty of the Russian Federation shall extend to the entirety of its territory.' Constitution of the Russian Federation <http://en.kremlin.ru/events/president/news/ copy/20604>. 
In the first instance, the provisions of the treaty in question prevail. Many treaties contain territorial application clauses, and in these cases the question will be one of treaty interpretation under the principles reflected in Article 31 VCLT. ${ }^{98}$ Various aspects of treaty interpretation may become relevant for the territorial application of a treaty with respect to annexed territory. For example, as the Singapore High Court's decision in Government of the Lao People's Republic v Sanum Investments Ltd shows, Article 31(3)(a) VCLT may be significant for a treaty's territorial application. ${ }^{99}$ That provision specifies that subsequent agreements between the parties shall be taken into account as an element of interpretation. In the present context, by contrast, it is primarily interpretation under Article 31(1) VCLT, and the meaning of 'territory' and 'jurisdiction' in a treaty's territorial application clauses, that are of concern.

\section{Geographic application by reference to 'territory'}

Many treaties contain a clause reflecting the general rule that the treaty shall apply in the parties' territory, or provide for obligations defined in part by reference to the parties' territory. Examples include extradition treaties, double taxation treaties, investment treaties, treaties creating an obligation to prosecute or extradite persons suspected of certain offenses, and environmental treaties. Certain treaties even contain twofold territorial application clauses that limit their application to the 'territory' of the parties both substantively and geographically. Bilateral investment treaties (BITs) can offer a useful illustration. For example, Article 2 the Austria-Ukraine BIT extends substantive protections to investments made on a party's sovereign territory, and Article 1(1) defines an investment by reference to the parties' territory. More generally, Article 11(1) provides that the treaty as a whole applies in the parties' sovereign territory. ${ }^{100}$ Here the applicability of the treaty itself extends to the sovereign territory of the parties. This position strictly speaking concerns a treaty's territorial application as a whole, not the performance of obligations under the treaty defined by reference to territory. Further, in the Austria-Ukraine BIT example, as is common in investment treaties, most of the parties' respective substantive obligations are only triggered in the event of an investment made in their respective sovereign

98 Arts 31 and 32 VCLT reflect rules of interpretation under customary international law. International jurisprudence confirming this position is voluminous. See generally R Gardiner, Treaty Interpretation (2nd edn, OUP 2015) 13-20; R Gardiner, 'The Vienna Convention Rules on Treaty Interpretation' in Hollis (n 25) 475.

99 See generally SD Murphy, 'The Relevance of Subsequent Agreement and Subsequent Practice for the Interpretation of Treaties' in G Nolte (ed), Treaties and Subsequent Practice (OUP 2013) 82.

100 Agreement for the promotion and reciprocal protection of investments (Austria-Ukraine) (signed 8 November 1996, entered into force 1 December 1997) 1995 UNTS 405. 
territory. Where such territorial restrictions are present, support for arguing that the treaty extends protections beyond de jure territory is fairly thin. ${ }^{101}$

Extradition treaties offer a further useful example and stand out for the central role that territory plays in the scope of obligations under such a treaty. For example, the United States-United Kingdom extradition treaty provides in Article 2(4), as part of the provisions on extraditable offenses, that '[i]f the offense has been committed outside the territory of the Requesting State, extradition shall be granted in accordance with the provision of the Treaty if the laws in the Requested State provide for the punishment of such conduct committed outside its territory in similar circumstances'. ${ }^{102}$ In other words, an aspect of the parties' obligation to extradite, under Article 1, is defined, in part, by reference to their territory by virtue of Article 2(4) of the treaty.

Other types of bilateral treaties with territorial clauses include, for instance, double taxation treaties. For example, Article 3(1)(b) of the UK-Indonesia double taxation agreement defines 'Indonesia' as 'the territory under the sovereignty of the Republic of Indonesia and such parts of the Continental Shelf and the adjacent seas, over which the Republic of Indonesia has sovereignty, sovereign rights as well as other rights in accordance with international law'. ${ }^{103}$ Qualifying words such as 'in conformity with international law' limit a treaty's application in certain territories or areas by explicit reference to the international lawfulness of a State's exercise of rights over such territories or areas. This type of clause illustrates the narrowest category of territorial limitation.

Among multilateral treaties, those treaties providing for an obligation to prosecute or extradite are particularly important, because this obligation is

101 The 2012 US model bilateral investment treaty also defines 'territory'. With respect to the United States this includes '(i) the customs territory of the United States, which includes the 50 states, the District of Columbia, and Puerto Rico; (ii) the foreign trade zones located in the United States and Puerto Rico'. Further, the US Model BIT defines 'covered investment' as 'an investment in [a Party's] territory of an investor of the other Party'. It also defines various other terms such as 'investor of a Party' by reference to investments in a party's territory, and delimits substantive obligations by reference to territory. Art 2(1) provides that the 'Treaty applies to measures adopted or maintained by a Party relating to: (a) investors of the other Party; (b) covered investments ... ' < <http://www.state.gov/documents/organization/188371.pdf>. Likewise, art 1(1) of the 2008 Germany model BIT for example defines 'investments' by reference to 'the territory of the other Contracting State' and art 1(3) defines 'investor' by reference to an investment in the territory of the other party. Art 1(4) defines 'territory' as 'the area of each Contracting State including the exclusive economic zone and the continental shelf insofar as international law allows the Contracting State concerned to exercise sovereign rights or jurisdiction in these areas' <http://www.italaw.com/sites/default/files/archive/ita1025.pdf $>$. In fact, such restrictions to a specific territory are part of an investment treaty's very purpose.

102 Extradition Treaty between the Government of the United Kingdom of Great Britain and Northern Ireland and the Government of the United States of America (with exchange of notes) (signed 31 March 2003, entered into force 26 April 2007) 2490 UNTS 249.

103 Agreement between the Government of the United Kingdom of Great Britain and Northern Ireland and the Government of the Republic of Indonesia for the avoidance of double taxation and the prevention of fiscal evasion with respect to taxes on income and capital gains (signed 5 April 1993, entered into force 14 April 1994) 2038 UNTS 303, art 3(1)(b). 
typically formulated by reference to a party's territory. For example, the Convention for the Suppression of Unlawful Acts against the Safety of Civil Aviation provides for such obligations to prosecute or extradite in Articles 59, after setting out the relevant offenses in Article 1. Certain aspects of the various obligations to prosecute or extradite have a specific territorial dimension, because these obligations are triggered where the offense is committed in the party's territory or the offender is present in its territory. ${ }^{104}$

Other multilateral treaties, such as environmental treaties, also illustrate the use of territorial application clauses. For example, the Stockholm Convention on Persistent Organic Pollutants provides for certain obligations that are defined by reference to a party's territory. ${ }^{105}$

The importance of a precise meaning of the term 'territory' is consequently crucial for determining the geographic scope of a treaty, or of obligations arising under it. The term 'territory' in a treaty must derive its meaning, in part, from its normative context. Yet here the interpretation of the term involves not only the taking into account of other rules of international law applicable in the relations between the parties according to the principle of 'systemic integration' reflected in Article 31(3)(c) VCLT, but, more importantly, also a notoriously complex legal and factual judgment that must come down in favour of one side or the other. In general, the normative context strongly favours a reading of 'territory' that is limited to territory to which a State can claim lawful title. In these circumstances, the interpretation of the term 'territory' constitutes a judgment with respect to the lawfulness of the territorial acquisition. The qualifier 'sovereign' would moreover, where it appears as part of the term 'sovereign territory', serve no function and be rendered meaningless if the term were interpreted to include, for instance, annexed territory. Any interpreter should construe the term 'sovereign', where it appears, in a way that renders it effective according to the ut magis valeat principle. ${ }^{106}$ Finally, where the exercise of territorial or maritime rights is qualified by words such as 'in accordance with international law' the conclusion that the geographic scope of the treaty or an obligation under it is restricted to de jure territory or maritime areas is impossible to overcome.

104 Convention for the Suppression of Unlawful Acts against the Safety of Civil Aviation (concluded 23 September 1971, entered into force 26 January 1973) 974 UNTS 177. See further ILC, 'Survey of multilateral conventions which may be of relevance for the work of the International Law Commission on the topic "The obligation to extradite or prosecute (aut dedere aut judicare)": Study by the Secretariat' (2010) UN Doc A/CN.4/630.

${ }^{105}$ For example, Annex A ('Elimination') of the Stockholm Convention on Persistent Organic Pollutants provides that parties must 'take[] steps to prevent exports of such articles that contain levels/concentrations of hexabromodiphenyl ether and heptabromodiphenyl ether exceeding those permitted for the sale, use, import or manufacture of those articles within the territory of the Party'. Stockholm Convention on Persistent Organic Pollutants (concluded 22 May 2001, as amended in 2009) 2256 UNTS 119, Annex A, Pt IV, art 1(b). See also Pt V, art 1(b).

106 On this principle, see Gardiner (2015) (n 98) 179-81. 


\section{Geographic application by reference to 'jurisdiction'}

Certain treaties, in particular multilateral ones, contain an application clause that extends their geographic application by reference to 'jurisdiction' instead of 'territory'. In the jurisprudence of international courts, some of these treaties have been held to apply extraterritorially in specific circumstances. ${ }^{107}$

Much of the jurisprudence on the extraterritorial application of treaties developed around the European Convention of Human Rights (ECHR) ${ }^{108}$ and around other treaties with a similar geographic application clause, including the ICCPR. ${ }^{109}$ For example, it is now well-established that a State in military occupation of a territory can engage its international responsibility for breach of its obligations under the ECHR for conduct attributable to it in the occupied territory, even where the occupation itself is internationally unlawful. The position with respect to the ICCPR remains more controversial and certain States, such as the United States and Israel, remain opposed to its extraterritorial application. ${ }^{110}$

The jurisprudence of the European Court of Human Rights (ECtHR) offers the most complete illustration. ${ }^{111}$ Much of the case law on this point turns on the geographic implications of the term 'jurisdiction' in Article 1 of the Convention for a party's obligation to secure Convention rights. In Loizidou $v$ Turkey (Preliminary Objections), the ECtHR noted that 'the concept of "jurisdiction" under this provision [Article 1 ECHR] is not restricted to the national territory of the High Contracting Parties'. ${ }^{112}$ It further observed that 'the responsibility of a Contracting Party may also arise when as a consequence of military action - whether lawful or unlawful - it exercises effective control of an area outside its national territory'. ${ }^{113}$ The Court broadly reiterated this position in its merits judgment in the same case. ${ }^{114}$ In Issa and Others $v$ Turkey, the Court noted, applying a test that focused on local relationships of control rather than overall control over territory, as in Loizidou or Cyprus v Turkey, ${ }^{115}$ that '[t]he essential question to be examined

107 Certain treaties also contain jurisdictional application clauses for specific rights only. See Milanović (n 77) 12; M Milanović, 'From Compromise to Principle: Clarifying the Concept of State Jurisdiction in Human Rights Treaties' (2008) 8 HRLRev 414.

108 Convention for the Protection of Human Rights and Fundamental Freedoms (signed 4 November 1950, entered into force 3 September 1953) 213 UNTS 221.

109 A comprehensive study of the extraterritorial application of treaties is beyond the scope of this article. The discussion here focuses on the practical implications of an application clause that refers to 'jurisdiction' as an instance of determining a treaty's scope of application through treaty interpretation.

111 For a review of the jurisprudence, see ibid 150-203.

112 Loizidou v Turkey (Preliminary Objections) (1995) ECHR Ser A no 310, para 62.

113 ibid. See also Karagiannis (n 25) 322-3.

114 Loizidou v Turkey (Merits) ECHR 1996-VI 2216, para 52. For a discussion of the meaning of 'effective control' in this context, and the relationship of this standard to the law of State responsibility, see Milanović (n 77) 136-41.

115 Cyprus v Turkey ECHR 2001-IV 1. 
in the instant case is whether at the relevant time Turkish troops conducted operations in the area where the killings took place'. ${ }^{116}$

Conversely, a Convention State's jurisdiction over its de jure territory may be reduced where its territory is under occupation. In Ilaşcu and Others v Moldova and Russia, ${ }^{117}$ the Court noted that the presumption that jurisdictional competence is primarily territorial ${ }^{118}$ 'may be limited in exceptional circumstances, particularly where a State is prevented from exercising its authority in part of its territory'. ${ }^{119}$ The Court proceeded to note that this 'may be as a result of military occupation by the armed forces of another State which effectively controls the territory concerned ..., acts of war or rebellion, or the acts of a foreign State supporting the installation of a separatist State within the territory of the State concerned'. ${ }^{120}$ In order to make such a determination, the Court stated, it 'must examine on the one hand all the objective facts capable of limiting the effective exercise of a State's authority over its territory, and on the other the State's own conduct'. ${ }^{121}$ The test in Ilaşcu represents a softening of the ECHR's position from Loizidou, and amounts to a recognition that certain obligations of the occupied State, the de jure sovereign, continue to apply. In this case, the ECtHR concluded that even though Moldova did not exercise effective control over the Transdniestrian region, Article 1 nevertheless imposed on Moldova a positive obligation to take measures within its power and in accordance with international law to secure individuals' Convention rights. ${ }^{122}$

In Jaloud v Netherlands, the Court made it clear that 'the status of "occupying power" within the meaning of Article 42 of the Hague Regulations, or lack of it, is not per se determinative' of the question whether jurisdiction arises for the purposes of Article $1 .{ }^{123}$ In other words, a third State - in this case the Netherlands - that is neither the occupying power nor the occupied State but

\footnotetext{
116 Issa and Others v Turkey (Final Judgment) App no 31821/96 (ECtHR, 30 March 2005) para 76.

117 Ilaşcu and Others v Moldova and Russia (Merits and Just Satisfaction) ECHR 2004-VII 1, paras 310-319.

118 See Banković and Others v Belgium and Others, ECHR 2001-XII 333, para 59. For criticism of this reasoning, see Milanović (n 107) 419ff.

119 Ilaşcu (n 117) para 312. 120 ibid.

121 ibid, para 313. In this case the ECtHR concluded that even though Moldova did not exercise effective control over the Transdniestrian region, art 1 nevertheless imposed on Moldova a positive obligation to take measures within its power and in accordance with international law to secure individuals' Convention rights.

122 ibid, paras 331 and 333 . The Court also held that by virtue of the effective control exercised by the Russian Federation over the region, the applicants in the case were within the Russian Federation's 'jurisdiction' for the purposes of art 1 ECHR, notwithstanding the fact that at the time of the relevant events the ECHR was not in force for the Russian Federation. The relevant acts were consequently capable of engaging the Russian Federation's international responsibility. ibid, paras 379-385. The Court also found that, after the coming into force of the Convention for the Russian Federation, there existed a 'continuous and uninterrupted link of responsibility on the part of the Russian Federation for the applicants' fate'. ibid, paras 386-394.

123 Jaloud $v$ Netherlands, App no 47708/08 (ECtHR, 20 November 2014) para 142.
} 
which exercises sufficient control in a particular area in an occupied State can be under an obligation to secure Convention rights by virtue of Article 1 ECHR. The ECtHR further held that a third State was not divested of jurisdiction solely by virtue of accepting the operational control of another State's military officer. ${ }^{124}$

In Al-Skeini and Others $v$ United Kingdom, the Court restated the basic principles concerning the meaning of 'jurisdiction' in Article 1 and its implications for the territorial applicability of the Convention. The Court confirmed that the term 'jurisdiction' in Article 1 operated as a 'threshold criterion' and was 'primarily territorial'. ${ }^{125}$ In exceptional circumstances, an act of a Convention party that was performed or which produced effects outside of its territory could constitute an exercise of jurisdiction within the meaning of Article 1. ${ }^{126}$ Examples include acts of diplomatic and consular agents, the exercise of public powers through consent, invitation or acquiescence of the government of the territory, and the use of force by a State's agents in another State's territory where such acts bring an individual under the control of the State's authorities. ${ }^{127}$ The ECtHR further articulated the exception arising with respect of effective control over an area:

Another exception to the principle that jurisdiction under Article 1 is limited to a State's own territory occurs when, as a consequence of lawful or unlawful military action, a Contracting State exercises effective control of an area outside that national territory. The obligation to secure, in such an area, the rights and freedoms set out in the Convention, derives from the fact of such control, whether it be exercised directly, through the Contracting State's own armed forces, or through a subordinate local administration. ${ }^{128}$

The Court again noted, as in previous decisions, that no detailed control over the policies and actions of the local administration was necessary for this purpose, ${ }^{129}$ and that the question whether a Convention State exercised effective control outside its own territory was a question of fact. ${ }^{130}$ The Court recalled that '[i]n determining whether effective control exists, the Court will primarily have reference to the strength of the State's military presence in the area' and that '[o]ther indicators may also be relevant, such as the extent to which its military, economic and political support for the local subordinate administration provides it with influence and control over the region'. ${ }^{131}$ Finally, the Court in Al-Skeini recalled generally that 'where the territory of one Convention State is occupied by the armed forces of another, the occupying State should in principle be held accountable under the Convention for breaches of human rights within the occupied territory'. ${ }^{132}$ This finding also sits comfortably with Article 47 GCIV, according to which protected persons in occupied territories shall not be deprived of the benefits

124 ibid, para 143.

125 Al-Skeini and Others v United Kingdom (Merits and Just Satisfaction) ECHR 2011-IV 99, paras 130-131. 126 ibid, paras 131-132. 127 ibid, paras 134-136.

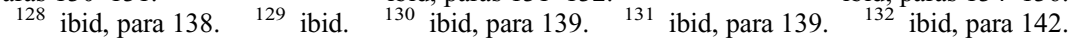


of the Convention by the annexation in whole or in part of the occupied territory by the occupying State.

Subsequent cases, including Catan and Others v Moldova and Russia, Jaloud and Pisari v Moldova and Russia, have confirmed the principles in $\mathrm{Al}$ Skeini with respect to the meaning of 'jurisdiction' in Article 1. ${ }^{133}$ In Catan, for example, the Court confirmed that jurisdiction within the meaning of Article 1 could arise from effective control of an area outside national territory as a result of lawful or unlawful military action, and that the controlling State is under an obligation by virtue of Article 1 to secure in the area under its control the full range of substantive rights under the Convention and the additional protocols it has ratified. ${ }^{134}$

Similarly, but also in contrast to the ECtHR, Article 2(1) ICCPR provides that '[e]ach State Party to the present Covenant undertakes to respect and ensure to all individuals within its territory and subject to its jurisdiction the rights recognized in the present Covenant'. ${ }^{135}$ This formulation is less straightforward than a simple reference to 'jurisdiction' as a threshold criterion, and has given rise to difficulties. In its advisory opinion concerning the Legal Consequences of the Construction of a Wall in the Occupied Palestinian Territory, however, the ICJ held that the ICCPR was in force with respect to acts attributable to Israel in the Occupied Palestinian Territory. ${ }^{136}$ In other words, it read the word 'and' in Article 2(1) as disjunctive rather than conjunctive, a position that the United States and Israel, for example, reject. ${ }^{137}$ The ICJ reached this finding in part on the basis of the ICCPR's object and purpose:

The Court would observe that, while the jurisdiction of States is primarily territorial, it may sometimes be exercised outside the national territory. Considering the object and purpose of the International Covenant on Civil and Political Rights, it would seem natural that, even when such is the case, States parties to the Covenant should be bound to comply with its provisions. ${ }^{138}$

The Human Rights Committee had, in General Comment 31, already adopted this view, ${ }^{139}$ though the ICJ did not refer to that document in its advisory opinion. Other multilateral instruments, not all of which are purely human rights treaties, have adopted less ambiguous formulations than the ICCPR.

133 Catan and others $v$ Moldova and Russia, ECHR 2012-V 309, paras 106-107; Jaloud (n 123) para 139; Pisari v Republic of Moldova and Russia (Final Judgment) App no 42139/12 (ECtHR, 19 October 2015) para 33.

135 ICCPR, art 2(1). See further Meron (n 89) 78.

136 Legal Consequences of the Construction of a Wall (n 65) para 111.

137 See Gondek (n 85) 279-285.

138 Legal Consequences of the Construction of a Wall (n 65) para 109. cf Dennis (n 81) 122-7.

139 UN Human Rights Committee, General Comment No 31, 'The Nature of the General Legal Obligation Imposed on States Parties to the Covenant' (29 March 2004) UN Doc CCPR/C/21/ Rev.1/Add.14, para 10. See further D McGoldrick, 'Extraterritorial Application of the International Covenant on Civil and Political Rights' in F Coomans and MT Kamminga (eds), Extraterritorial Application of Human Rights Treaties (Intersentia 2004) 41. 
For example, Article 1(1) of the American Convention on Human Rights refers only to 'jurisdiction' and not to 'territory'. ${ }^{140}$ Article 2(1) CAT provides: 'Each State Party shall take effective legislative, administrative, judicial or other measures to prevent acts of torture in any territory under its jurisdiction.' ${ }^{141}$ Article 3 CERD provides that 'States Parties particularly condemn racial segregation and apartheid and undertake to prevent, prohibit and eradicate all practices of this nature in territories under their jurisdiction.' ${ }^{142}$ Article 2(1) of the Convention on the Rights of the Child provides that 'States Parties shall respect and ensure the rights set forth in the present Convention to each child within their jurisdiction.' ${ }^{143}$ The ICESCR and the Convention on the Elimination of Discrimination against Women contain no geographic application clause. Pursuant to the ICJ's approach in Legal Consequences of the Construction of a Wall, however, the object and purpose of such treaties is arguably to regulate the parties' conduct generally, rather than with respect to a specific territory.

The question ultimately is whether a specific term, notably 'jurisdiction', narrows or broadens the territorial application of treaties as compared to the position under Article 15 VCST and Article 29 VCLT. Prima facie, it does not necessarily do one or the other. A jurisdictional application clause need not replace, but can coexist with, the position under Article 15 VCST and Article 29 VCLT. An application clause by reference to jurisdiction, or indeed a reference to territory in a substantive provision, typically modifies the threshold criterion for the performance of a specific treaty obligation or obligations under the treaty as a whole. The position concerning a treaty's territorial application pursuant to the rules in Articles 15 VCST and 29 VCLT, by contrast, as well as a general application clause that refers to 'territory' in relation to the treaty's applicability as a whole, governs the territorial applicability of the treaty by reference to a characteristic of the treaty party, namely its territorial limits under international law and internal arrangements concerning the position of federal states or of the metropolitan State vis-à-vis its other possessions.

Thus, for example, even the ECHR in Article 56 contains a territorial application clause that allows parties to extend the applicability of the convention to non-metropolitan territories. ${ }^{144}$ Article 56 addresses the question whether the ECHR applies territorially to overseas territories and dependencies. It allows contracting States to make a declaration upon ratification of the Convention that the instrument should extend to any or all territories for the international relations of which the State is responsible.

\footnotetext{
140 American Convention on Human Rights (signed 22 November 1969, entered into force 18 July 1978) 1144 UNTS 123.

${ }^{141} \mathrm{CAT}$, art 2(1). Other provisions also include references to jurisdiction as a threshold criterion. See eg arts 7 and 16 .

142 CERD, art 3.

${ }^{143}$ Convention on the Rights of the Child (adopted 20 November 1989, entered into force 2 September 1990) 1577 UNTS 3, art 2(1). $\quad{ }^{144}$ For discussion, see Milanović (n 77) 14-16.
} 
This provision, however, addresses a different question than Article 1. Article 56 concerns the geographic applicability of the treaty in relation to a party's territorial and internal constitutional character, whereas Article 1 specifies the threshold requirement in relation to a party's obligation to secure Convention rights in a specific territory. ${ }^{145}$ In Al-Skeini, the ECtHR held that "the "effective control" principle of jurisdiction ... does not replace the system of declarations under Article 56 of the Convention'. ${ }^{146}$ Instead, the ECtHR found that

The existence of this mechanism, which was included in the Convention for historical reasons, cannot be interpreted in present conditions as limiting the scope of the term 'jurisdiction' in Article 1. The situations covered by the "effective control" principle are clearly separate and distinct from circumstances where a Contracting State has not, through a declaration under Article 56, extended the Convention or any of its Protocols to an overseas territory for whose international relations it is responsible $\ldots .{ }^{147}$

This is a relevant distinction with respect to annexed territory, since the above case law in relation to occupied territory shows that it is more straightforward to argue that an annexing State may be required to perform specific treaty obligations in the annexed territory than that the treaty as a whole applies with respect to that territory as a consequence of State succession.

Yet as international jurisprudence demonstrates, an application clause by reference to a State party's 'jurisdiction' for all intents and purposes broadens a treaty's geographic scope of application, as far as the performance of obligations is concerned, precisely because it can accommodate extraterritorial application without straining the text of the treaty's relevant provisions. In other words, such a case arguably falls within the 'otherwise provides' language of Article 29 VCLT. Given the lack of change to the legal status of an annexed piece of territory as a result of the annexation, any possible application of the annexing State's treaties in the territory would perforce have to be extraterritorial. Finally, the question may in practice not even arise in so stark a form. Again, where a State has annexed part of another State's territory, it cannot consistently maintain its claim to sovereignty over the territory and at the same time the position that its treaties do not apply with respect to that territory. Indeed, the application of its treaties to that territory is part of its claim to sovereignty over the territory under international law - a claim which may have a preclusive effect.

From the dispossessed State's perspective the situation looks different in a case of annexation. Where the dispossessed State no longer exercises any effective control over the territory, individuals in the territory may no longer be under the dispossessed State's jurisdiction for the purposes of an instrument the geographic reach of which is defined by reference to jurisdiction. However,

\footnotetext{
${ }^{145}$ Art 56 addresses the question whether the ECHR applies in overseas territories and dependencies. The provision allows States to make such a determination upon deposit of their instrument of ratification. $\quad{ }^{146}$ Al-Skeini (n 125) para $140 . \quad 147$ ibid.
} 
as Ilaşcu shows, even the State no longer in effective control may have certain continuing obligations.

\section{Status of the 'Dispossessed' State's Treaties in Annexed Territory}

Prima facie, since the dispossessed State typically maintains its claim to title over the annexed territory, its treaties should continue to apply in the territory. The result would be that potentially certain treaties of both the annexing and the dispossessed State could apply with respect to the same territory at the same time, even if acts on the territory are not likely to be attributable to the dispossessed State.

The application of the 'annexing' State's treaties rather than the 'dispossessed' State's treaties in that territory can, from certain perspectives, even be the less favourable outcome. For example, many States' investment treaties with Russia that date to the time of the Soviet Union limit the grant of arbitral jurisdiction to the assessment of the quantum damages in the event of an expropriation, and leave questions of responsibility outside the scope of arbitral jurisdiction. ${ }^{148}$ Thus should Russia's investment treaties govern investments in the Crimea, at least those made after March 2014 (though a precise date is difficult to identify), ${ }^{149}$ foreign investors from certain States may have little recourse to dispute resolution to determine issues of responsibility. Conversely, however, Ukraine's BITs may in practice offer little more protection, because any relevant acts are unlikely to be attributable to Ukraine.

In specific cases, however, the applicability of the dispossessed State's treaties to the annexed territory may be affected by the limitations in Article 15 VCST, or by the doctrines, respectively, of supervening impossibility of performance or rebus sic stantibus, reflected in Articles 61 and 62 VCLT respectively. Even if the blanket limitation under Article 6 VCST excluding cases of unlawfulness from the scope of the 1978 Convention were-for the sake of argument - not operative, a possible substitution in sovereignty or effective control over a territory could conceivably, in certain cases, ipso facto either render the treaty impossible to perform or constitute such a

\footnotetext{
148 For a discussion of a jurisdictional clause of this kind, see eg RosInvestCo $v$ Russian Federation, Award on Jurisdiction, 5 October 2007, SCC Arbitration V 079/2005, paras 76-123 (the provision in question was art 8 of the 1989 United Kingdom-USSR BIT); Renta 4 SVSA and others $v$ Russian Federation, Award on Preliminary Objections, 20 March 2009, SCC Arbitration V 024/2007, paras 17-67 (the relevant jurisdictional provision was art 10 of the 1991 Spain-USSR BIT). This position assumes that Russia is the successor State to the USSR as a party to these bilateral treaties. This is not necessarily an unproblematic claim. For discussion, see $\mathrm{P}$ Dumberry, 'An Uncharted Question of State Succession: Are New States Automatically Bound by the BITs Concluded by Predecessor States before Independence?' (2015) 6 Journal of International Dispute Settlement 90-3.

149 According to art 28 VCLT the default rule is that treaties have no retroactive application.
} 
change of circumstance in a bilateral treaty so as to trigger one or both of the limitations under Article 15, though this need not necessarily be the case. ${ }^{150}$

A treaty's object and purpose could, for example, include the physical territory in question, or even part of it, where the treaty's material application pertains specifically to that territory, its features, or conduct on it. This could even include treaties that do not relate explicitly to the territory, but govern, for example, environmental issues such as emissions, preservation of natural habitat or endangered species, which, due to certain features on the territory, affect it in a particular way. In such a case, a substitution in the sovereignty over the territory in question, or even - as here-a change in the effective control over it, could conceivably be incompatible with the treaty's object and purpose or 'radically change' the circumstances of the treaty's operation within the meaning of the rule reflected in Article 15 VCST. In general, this might in particular be the case where the treaty is one that is intuitu personae, ie, where the identity of one party was an essential condition of the other party's entering into the treaty. In such a case, for example involving a treaty of alliance, the treaty may terminate as a result of a fundamental change of circumstance. ${ }^{151}$ It is unlikely that a multilateral treaty would be caught by one or both of the limitations under Article 15 VCST, particularly where, as many such treaties do, it regulates State conduct generally. A bilateral treaty could more easily be captured by one of the limitations under Article 15 VCST. ${ }^{152}$

The question arises whether the respective tests for the applicability of the limitations under Article 15 VCST are congruent with the test giving rise to a fundamental change of circumstances under the doctrine of rebus sic stantibus under Article 62 VCLT. That doctrine, which in practice is limited to exceptional circumstances and finds application only in exceptional cases, seems, however, to have been designed precisely for changes as fundamental as the identity of the State in control of a certain territory. ${ }^{153}$ Consequently, it is conceivable that if a treaty was intuitu personae and related specifically to certain territory, an annexation of that territory by a third State could conceivably lead to the treaty's termination or suspension under the doctrine of rebus sic stantibus. ${ }^{154}$

The 'dispossessed' State may also be in a position to invoke the doctrine of supervening impossibility of performance, though the necessary 'permanent disappearance or destruction of an object indispensable for the execution of the treaty' under Article 61(1) VCLT may be limited to physical objects and

150 See Sanum (n 35) para 246: 'The Tribunal notes first that Article 15 does not distinguish between multilateral and bilateral treaties. Second, the Tribunal considers that it would be excessive to say that all bilateral treaties are so personal, so related to intuitu personae questions that they cannot survive a State's succession.' (emphasis in original).

151 See Stern (n 31) $170 . \quad{ }_{152}$ See Sanum (n 35) para 276.

153 See M Fitzmaurice, 'Exceptional Circumstances and Treaty Commitments' in Hollis (n 25) $612-24$.

154 For a rare case involving the application of the rebus sic stantibus principle, see Case C-162/ 96 A Racke GmbH \& Co v Hauptzollamt Mainz [1998] 3 CMLR 219. 
may not include the disappearance of a legal treaty regime. The ICJ in Gabčikovo-Nagymaros Project (Hungary/Slovakia) left this question open, and the principle in any event remains very difficult to invoke. ${ }^{155}$ Any impossibility of performance would at least in part depend on the extent of the dispossessed State's remaining control over the territory. The general consequence of these rules is termination, which may well be an appropriate result if the treaty was intuitu personae and related specifically to the territory in question. Termination would seem particularly appropriate where the annexing State's effective control over the territory endures or is anticipated to endure indefinitely or for a very long period of time. For the purposes of State responsibility, in any event, it is unlikely that any acts on the territory will be attributable to the dispossessed State in these circumstances. The dispossessed State might also be in a position to plead force majeure as a circumstance precluding wrongfulness under the law of State responsibility, if the forcible annexation of its territory created a situation of impossibility with respect to the performance of its obligations. ${ }^{156}$

Alternatively, it may be a more appropriate consequence that, as a general rule, the application of the dispossessed State's treaties in the territory is merely suspended. Under Article 61(2), suspension is in any event the only possible consequence where impossibility of performance is merely temporary. Either way, however, neither termination nor suspension is automatic under Article 61 or 62 VCLT, but only occurs upon a party's notification pursuant to the procedures in Articles 65-68 VCLT. Consequently, any effect under these doctrines in the present scenario would depend on the dispossessed State's notification in accordance with these provisions.

\section{PARALLELS FROM EXCEPTIONS TO THE OBLIGATION OF NON-RECOGNITION}

Even independently of a treaty's object and purpose or its provisions, an appeal to other areas of international law can lend support to the position that certain treaties to which the annexing State is a party may apply in the annexed territory, by virtue of the annexing State's degree of control over the territory coupled with a claim to sovereignty. It seems possible for other States to acknowledge this applicability of certain treaties while at the same time maintaining a position of non-recognition towards the purported change to the status of the territory.

This position provides a possible further solution to the difficulties arising out of an annexation for the application of treaties in the territory. Indeed, it is not necessarily fatal to the objectives and policies underlying the obligation of collective non-recognition to accept the possibility of a limited form of treaty

\footnotetext{
155 See Gabčikovo-Nagymaros Project (n 21) paras 102-103; Fitzmaurice (n 153) 606-612.

156 See ARSIWA, art 23.
} 
succession in these circumstances. This is because the obligation of nonrecognition is already subject to an important limitation. The question here is not whether the territorial application of treaties to annexed territory is justified on the basis of one of the accepted limitations to the moving treatyfrontiers, as reflected in Articles 15 VCST and 29 VCLT, but rather whether there is room under general international law for a limited 'succession' of certain treaties in annexed territory, in cases where the treaty cannot otherwise straightforwardly be applied extraterritorially on the basis of the generality of the obligations it creates or on the basis of its provisions.

The ICJ articulated a limitation to the obligation of collective non-recognition in Legal Consequences for States of the Continued Presence of South Africa in Namibia (South West Africa), notwithstanding Security Council Resolution 276 (1970), ${ }^{157}$ and the European Court of Human Rights confirmed this limitation in Loizidou v Turkey (Merits) ${ }^{158}$ and in Cyprus v Turkey. ${ }^{159}$ The same policy considerations that drove the development of that limitation also speak in favour of accepting a limited 'succession' of certain treaties in annexed territory. It is the lesser of two evils to attach legal consequences to circumstances on the ground when doing so in fact amounts to taking the stricter approach to the scope of the annexing State's international legal obligations. This practical solution, which does not formally depart from the obligation of non-recognition any more than the other limitations previously articulated in the jurisprudence of the ICJ and the ECtHR, is particularly compelling where this position generates greater international legal protection for the rights of individuals.

In general, the obligation of non-recognition in the event of a serious breach of an obligation under a peremptory norm does not extend in a blanket fashion to all official acts, especially where there is a risk that non-recognition may prejudice individuals' rights. ${ }^{160}$ Thus there is an exception in favour of those official acts on the part of the wrongdoing State or entity which, if they remained unrecognized by other States, would deprive individuals of the 'advantages derived from international co-operation'. ${ }^{161}$ In its Namibia advisory opinion the ICJ named as examples the recognition of acts performed by the government of South Africa on behalf of the territory of South West Africa such as 'the registration of births, deaths and marriages, the effects of which can be ignored only to the detriment of the inhabitants of the Territory'. ${ }^{162}$ For instance, where an unlawfully occupying power performs these or similar acts of civil registration, and their non-recognition by other

\footnotetext{
157 Legal Consequences for States of the Continued Presence of South Africa in Namibia (South West Africa) notwithstanding Security Council Resolution 276 (1970) [1971] ICJ 16.

158 Loizidou (Merits) (n 114). ${ }_{159}$ Cyprus v Turkey (n 115).

160 See ILC Yearbook 2001, vol II (Pt Two) 115 (ARSIWA, art 41 commentary).

161 Namibia (n 157) para 125.

162 ibid. For a discussion of the pleadings by States that led to the inclusion of this passage, see Cyprus v Turkey (n 115) para 94.
} 
States may deprive the inhabitants of the 'advantages derived from international co-operation' 163 or indeed, even worse, of a human right, the international legal obligation not to recognize the legality of the situation must be qualified to the extent of these acts, because of the individual interests at stake. An analogous argument also has force with respect to the inhabitants of the annexed territory in the present example, when those rights find greater protection if the annexing State is under an obligation in the territory to secure individuals' enjoyment of these rights.

While the obligation of non-recognition and the above-mentioned limit to it in the Namibia advisory opinion were based on the Charter, the ECtHR's judgment in Loizidou $v$ Turkey (Merits) suggested that this exception to the obligation of non-recognition was part of general international law. ${ }^{164}$ The ECtHR elaborated further upon this position in its judgment in Cyprus $v$ Turkey. In that judgment, the Court noted that 'the obligation to disregard acts of de facto entities is far from absolute', ${ }^{165}$ and that non-recognition of the acts of the de facto authorities that concern individuals would strip the inhabitants of their rights in an international setting. ${ }^{166}$ The Court noted that this was true in particular with respect to private-law relationships and acts of de facto authorities regulating such relationships. ${ }^{167}$ It concluded in that case that it could not disregard the courts set up by the 'Turkish Republic of Northern Cyprus' (TRNC), ${ }^{168}$ but that recognizing 'the effectiveness of those bodies for the limited purpose of protecting the rights of the territory's inhabitants does not, in the Court's view and following the Advisory Opinion of the International Court of Justice [in Namibia], legitimise the "TRNC" in any way'. ${ }^{169}$ At the same time, the ECtHR stressed that this acknowledgment of its de facto institutions did not result in a legal recognition of the TRNC. The ECtHR's judgment in Cyprus $v$ Turkey thus constituted a softening of its position on the question and an acceptance, of sorts, of the status quo.

Indeed, when pressed, certain international courts have sooner compromised on the effects of a territorial acquisition, or claim to statehood, not in accordance with international law than allow the stringent adherence to non-recognition of unlawful territorial changes to occur at the expense of individuals' rights. The parallel with respect to the general rule concerning the territorial application of treaties has persuasive force. Such reasoning would allow an international court or tribunal to find that a treaty applies in annexed territory. A rule requiring a

163 Namibia (n 157) para 125. ${ }^{164}$ Loizidou (Merits) (n 114) para 45; Namibia (n 157) para 125.

165 Cyprus v Turkey (n 115) para 96. 166 ibid. 167 ibid, para 97.

168 ibid, para 98.

169 ibid, para 92. To the extent these de facto institutions offer possible remedies, individuals may be required to exhaust these local remedies where they are available before turning to a treaty-based organ, such as a human rights body, for a remedy. Cyprus v Turkey (n 115) paras 91, 98. The Court also took this position on domestic remedies in Demopoulos v Turkey. Demopoulos v Turkey (2010) 50 EHRR SE14, paras 68-129. The ECtHR here was attempting to steer a course that allowed limited recognition of de facto power, that is, of realities on the ground, for the purpose of safeguarding the rights of individuals. A similar concern arises in the present situation. 
certain degree of extraterritorial application of treaties in these circumstances is not the most stringent form of non-recognition. However, it represents a nuanced approach to the non-recognition of the annexing State's claim to the territory that takes other important considerations into account.

\section{CONCLUSIONS}

In the absence of a territorial or jurisdictional application clause in a treaty, governing either the treaty as a whole or individual obligations, the moving treaty-frontiers rule under general international law and reflected in Articles 29 VCLT and 15 VCST will govern the treaty's geographic applicability.

The moving treaty-frontiers rule is itself formulated by reference to 'territory'. The rule, however, may not permit a reading of the term 'territory' in such a way that includes annexed territory, which is ex hypothesi not part of the annexing State's de jure territory. The same holds true for an unqualified reference to 'territory' in a treaty's provisions and, a fortiori, where the reference is to 'sovereign territory' or territory over which a State exercises rights or jurisdiction in accordance with international law. The possible extraterritorial application of a treaty is a result, in first instance, of its object and purpose, including notably the type of State conduct it regulates, as well as of the interpretation of its provisions.

However, to the extent one accepts a position that draws on parallels to the limitations to non-recognition, there may be room to hold that a treaty can apply in annexed territory as a result of de facto moving treaty-frontiers, to the extent the treaty provisions so permit. This position remains largely untested in practice. That said, such an exception may play an important role where the rights of individuals under a treaty are at stake, and where none of the exceptions reflected in Articles 15 VCST and Article 29 VCLT or their equivalents under customary international law apply and the treaty has no extraterritorial application by virtue of its provisions. In such a case, the application of an annexing State's treaties in territory over which it is not the lawful sovereign yet over which it exercises sovereign powers may be the only solution that avoids a legal vacuum. 